\title{
Study of the Relationship Between Entrepreneurial Services and Competitive Benefits of the Staff of Ahwaz University of Medical Sciences with the Mediator Role of Interactive and Supportive Innovation
}

\author{
OMIDI Fereydoon ${ }^{10}$, JORFI Adibeh ${ }^{11}$, JORFI Fakhri ${ }^{12}$
}

\begin{abstract}
Entrepreneurship, as a new phenomenon in economics, in a broad and multifaceted interaction with market orientation, plays a decisive role in improvement and the performance of organizations. Nowadays, achieving a sustainable competitive advantage in organizations is crucial to obtain appropriate financial results for which innovation is one of the most significant ways. One of the most important features of innovation which might lead to competitive advantage, is the asynchronous use of it by other competitors and the difficulty in imitating and duplicating it, which itself requires culture implementation and entrepreneurial strategies. The relationship between entrepreneurship and market orientation has been investigated in the last two decades theoretically and practically. To this end, the aim of this research is the study of the relationship between entrepreneurial services and competitive benefits with the mediator role of interactive and supportive innovation. The statistical population of this study is 150 people selected among the staff of Ahwaz university of medical sciences. Employing descriptive and inferential statistics in SPSS, the data were analyzed. In order to understand the current status of respondents in terms of the amount of each variable under study, the relationship between variables is investigated using single sample t-test and Pearson correlation coefficient. They are also analyzed through structural equations and path coefficient analysis. Results represent a close relationship between interactive and supportive innovation with competitive advantage in the selected companies.
\end{abstract}

Keywords: Entrepreneurial Services; Interactive Innovation; Supportive Innovation, Path Analysis

JEL: L26

UDC: 378.6:61]:005.31(55)

005.961:005.914.3(55)

COBISS.SR-ID 265400844

Introduction

\footnotetext{
${ }^{10}$ International Business Management of Khorramshahr - Persian Gulf, Islamic Azad University, Khorramshahr, Iran. email:Omidi2328@gmail.com.

${ }^{11}$ International Business Management of Khorramshahr - Persian Gulf, Islamic Azad University, Khorramshahr, Iran. email:adibehjorfi@gmail.com.

${ }^{12}$ Shahid Chamran University, Ahwaz, Iran. email: aria-f2003@yahoo.com
} 
A penetrating look at the world reveals the truth that "the world today is very different from the past". This difference refers back to some dominant features namely, globalization of the economy, mass production and surplus capacity in most markets, time-based competition, massive information and efficiency of communication and knowledge and customer's increasing information and power and all these represent the integration of global markets, increasing complexity of markets and the dynamics of processing environment of companies and manufacturing and service enterprises. In such place, organizations survival and success are sustainable in creation, maintenance and perseverance of the competitive advantage.

Obviously, achieving this goal, demands an intelligent design of competitive path which is causally obscure and socially and managerially complicated. Yet, understanding concepts and content features, various kinds of competitive advantages and their causal area, pave the way for the design and performance of this approach.

Many experts believe that new organizational strategies with novel structures should be followed in order to produce goods and services with the lowest cost and best quality meeting customers' needs; in a way that the world markets could be conquered. Therefore, if we want to have a successful economy, we need successful companies in competitive environments and this requires a powerful and autonomous manpower. Entrepreneurship, creativity, innovation and risky businesses are crucial elements in the economy for country development. Hence, in each organization, if there is an entrepreneurship, there will be employment and technology transference. Entrepreneurs are the agents of realization, creation and development of new markets. They are capable to see the gaps of markets and identify the opportunities well; in other words, entrepreneurship is nothing but recognition and optimal use of an opportunity.

Therefore, the present research takes entrepreneurship as an appropriate strategy for an interaction with sustainable competitive advantage.

\section{Problem Statement}

Today, the sustainable competitive advantage is achieved if companies bring superior value and sustainability for their customers. The growing importance of services puts more emphasis on the need for service-oriented approach for value creation (Bitner \& Brown, 2008). Service innovation improves the overall performance of organization and this, in turn, is an important resource to achieve competitive advantage (Gray, Matear, Deans \& Garett, 2007). However, there are different gaps or vacuums should be considered (Hipp \& Grupp, 2005). First, despite identifying the growing key differences between service innovation and production innovation, most approaches have the concept of service innovation based on goods production. Certain features of services should be realized clearer to facilitate the concept of innovation in services. Second, most studies have not widely investigated the sources limitations to access innovation in companies, while most companies are managed under dependency and environmental limitations (Casciaro \& Piskoriski, 2005). And also, there are insufficient information on the way companies can create value through identical and distinct resources. In many cases, entrepreneurial designs are run in environments encountering short supplies where companies adapt themselves to "instrumentation or creating value from resource combination". That is, strategically, the available resource combination is used to develop unique opportunities and further value for customers (Beker \& Nelson, 2005).

Regarding these gaps and creating a competitive strategic viewpoint, lead to investigating the role of entrepreneurship services, resource combination (instrumentation) in service innovation and the process of competitive advantage. As a new concept, this research analyzes the created value by service innovation (O'Cass \& Ngo, 2010), moreover, as a service provider, it is divided into two types: interactive innovation (i.e. direct value creation 
experienced by customer) and supportive innovation (indirect value creation through a mediator or protector).

Several key factors are resulted from reanalyzing the service innovation based on companies' functional information. First of all, these information claim that service innovation influences the function positively and empowers the company to create higher value compared to other competitors. For instance, service innovation which combines the knowledge of customers and first level employees, influences sales performance, costs and companies' competitive function. Similarly, the difference in services and focus on service innovation, develop competitive advantage (Kastafson et al., 2011). However, the attention revolves around the results of service innovation, there are little empirical researches on the assessment of superior and permanent benefits of market position brought by service companies. The existing studies scrutinize integrated views in areas that are supported by some researchers; while other researchers propose a view opposing service innovation based on sustainable competitive advantage. Ease of use of duplicate services and the possible problems in terms of service innovation registration are considered as common reasons which are represented by those who stand against the service innovation based on sustainable competitive advantage.

But those who possess a supportive view hereof, observe that the basis of the stable and superior function is hidden in key capabilities recognized and developed by the company. Several researches on the function based on service innovation describe a view based on company's capabilities. A view based on competitive strategic capabilities invites the company to achieve competitive advantage through their distinct capabilities.

Some scholars found out that unique features or differential capabilities are regarded as the key factor in achieving a sustainable competitive advantage.

However, this discussion remains unresolved, the previous records and the strategy of service innovation in other service industries should be studied and assessed deeply in different researches. Secondly, service innovation is distinct from manufacture innovation with noticeable differences. For example, the incremental and sustainable nature of service innovation and lack of evolutionary levels and research and development units in service companies represent that service innovation is naturally different from manufacture innovation.

Researches on service innovation show that the convergence among employees, suppliers and partners in innovation process, is beneficent for the function of service companies and also services growth and innovation result from communication out of the company which attract and retain innovators to the company. However, to create innovation in services, scholars put emphasis on communicative and interactive aspects and this makes the function results related to services innovation to be influenced, there are little researches on the way a company can achieve a stable function through innovation.

Finally, concepts and hypotheses of service innovation originates from a broad range of theoretical aspects to investigate the existing empirical evidence related to innovation results in low amounts which lead to an innovation-based function.

Anyway, infrastructure strategies of resource combination, by service companies, lead to innovative actions which have not been considered widely. In terms of environmental resource limitations, Baker \& Nelson (2005) claim that: "resource combination, to access new goals, is sometimes employed as a new mechanism leading to innovation discovery through offering new services to customers by means of the available resources".

\section{Significance of the Study}

One of the key requirements for companies' success, is how can the competitive advantages be sustained? For the development and deployment of a competitive advantage, 
companies should possess the capabilities to be used in creating valuable, inimitable, scarce and irreplaceable resources (Movaghar \& Mousavi, 1393).

To be able to survive in new competitive paradigms among organizations, which is a totally competitive and knowledge-based area, today's organizations should regard innovation as a crucial strategy and while recognizing environmental change and evolution, they should identify organizational index influencing organizational innovation and be amenable to changes. Regarding the importance of innovation and competitive advantage for business survival and the necessity for companies and organizations to be familiar with such issues, in the present study, they are elaborated on entitled "study of relationship between entrepreneurship services and competitive advantages with the mediator role of interactive and supportive innovation" to use the results in the best way.

\section{Operational Definitions}

This part is committed to brief definitions of the employed variables.

Competitive Advantage

To better understand any subject, first its definition should be proposed.

Obviously, the more comprehensive the definition is, the better understanding of a subject will result. In this regard, some definitions related to competitive advantage given by experts will be suggested: "competitive advantage is company's increasing attractions of suggestion compared to competitors in customers' point of view" (J Kigan, 1394). "Competitive advantage of company's available values for customers, in a way that these values are higher than customer's costs".

Regarding the suggested definitions, competitive advantage shows that the direct relationship among values in customer's point of view, the offered values by company and the offered values by competitors, determine the requirements and dimensions of competitive advantage. As from the customer's point of view, the comparison of values offered by the company with the values supplied by competitors is more consistent with the desired values and disciplines, it can be said that the company has a competitive advantage in one or more indices; it a way that this advantage causes more customer's attraction compared to other competitors.

Given the theoretical foundations of the subject and the actual and objective dynamics of competition, the competitive advantage can be divided into five types:

a) Situational advantage vs. kinetic or dynamic advantage;

b) Congregant advantage vs. inconsistent advantage;

c) Obvious advantage vs. intangible advantage;

d) Simple advantage vs. compound advantage;

e) Temporary advantage vs. lasting advantage.

\section{Entrepreneurship}

Entrepreneurship is subject has attracted the attention of educational circles in the world since the end of the twentieth century. A review of a history of entrepreneurship has proven that this term was created in economics and by economist and then it entered the schools of other fields (Chegeni, 1388). There are different definitions for entrepreneurship. Social and management scientists, psychologists, economists, each has a specific definition for entrepreneurship, but they all share this common point that entrepreneurs, as the economic axis, substitute the old and insufficient methods with modern efficient ones which mobilizes the economic system. The entrepreneur is a person who seeks for innovation such as producing new products, suggesting modern method in production process, finding new resources, 
creating a new organization in business, opening a new market and influencing financiers (Rahimian, 1388).

Therefore, entrepreneurship is the process of innovation in which the entrepreneur spends time and effort and accepts some possible financial, mental and social risks to achieve funds, personal satisfaction and independence. The current economic condition, in which our country encounters major problems such as brain drain, deterioration of government investment, lack of economic mobility and growth, training entrepreneurs has the most significance (Ardakani et al., 1388).

\section{Innovation}

Brant defines innovation as any new behavior or thought which differs qualitatively and Draker regards it as any attempt to create purposeful and centralized changes in a business enterprise or social potentials (Rahman Seresht \& Hashemi, 1387). Innovation is an effective method to accelerate the growth and profitability in service companies, associated with new methods of value creation for both customers and companies. Innovation in service includes: a) interactive innovation: tends to more customers and looks for behavioral and emotional responses from customers encountered with new value or concept. b) Supportive innovation: novel values which interact with customers and supports offering new integrated services with configuration (Movaghar \& Mousavi, 1393).

\section{Methodology}

Innovation is an effective method to accelerate the growth and profitability in service companies, associated with new methods of value creation for both customers and companies.

While previous approaches had investigated service dimensions, type and level for conceptualization of service innovation, as a method through which service companies create value by means of innovation and customer-orientation, it was under little empirical attention (Carman \& Langeard, 1980). The concept that innovation is mainly a physical product and competitive advantage is provoked by entrepreneurship, is well proved in the strategic researches (Ahuja \& Lampert, 2001). Discovery, creation and exploitation of goods and future services and results are regarded as a profit or principal interest in the field of entrepreneurship (Venkatarama, 1997). In return, there are several differences between service manufacture and innovation, some of which may be considered as innovation obstacles. Service innovation contains possible strategic changes in value chain. On the other hand, companies which are more customer-centric and depend on their customers as input factor in the innovation process, they probably focus on a better placement of customers who need innovation (Alam, 2002).

This focus might be effective in leading the company to innovation. To support such companies which produce more ideas and accelerate their performance, they often produce more and more innovations.

In order to effectively implement new services, there should be a strong interaction between the offered value propositions by a company and supportive systems and the main process. On this interaction, Mahajan and Akripol and Chis, represent a mutual relationship between operational tasks and marketing. In the case of project-driven companies, when the company develops a new field of expertise as a part of its propositions, it needs new programs to provide new resources and achieve special relevant features to support and create value through new innovations.

In the case of competitive advantage and innovation, it is claimed that the sustainable competitive advantage refers to company's access "a top market position" through competitors with better performance. The previous researches show that while retaining a competitive 
advantage is difficult in unstable environment, competitive advantage in stable business environments can be sustainable (Essenhart \& Martin, 2000). However, researchers investigated the "dynamism obstacles" (Porter, 1980), "the factor of shortage of markets" and denotative mechanism (Rumlet, 1984) for competitive advantage stabilization, there are limited researches which empirically prove that which factors support superior economic function. This research confirms that the definition of the balance of sustainable competitive advantage which is proposed by Barney, claims that "a company claims that to have a sustainable competitive advantage which is operating a value-creating strategy, it should not function or being duplicated for other competitors simultaneously". A key factor leading to the stability of a competitive advantage, is competitors' incapability in imitation and duplication the value structure-based innovation which creates the advantage.

The inability to copy and paste is related to separation mechanisms which increase the costs of strategy imitation, is regarded as a barrier to imitation. That way, this special description is consistent with the previous researches on competitive strategy which run the sustainable competitive advantage (Weerawardena \& O'Cass. 2004).

\section{Review of Literature}

The conducted domstic and foreign studies are as follows:

\section{Domestic Studies}

Naiyeri et al., (1394) have proposed a model for "determining the role of market orientation role in promoting the level of organizational innovation in banking system (case study: Bank of Hekmat Iranian”. The results confirm the suggested model. Market orientation and its components, have a positive effect on organizational innovation in Bank of Hekmat.

There is also a significance gap between the existing condition and the desired features from respondents' point of view.

Movaghar \& Mousavi diva (1393) have conducted the study entitled "investigating the role of service entrepreneurship and bricolage in sustainable competitive advantage: specification of the role of interactive and supportive innovation" and along with a comprehensive overview of the subject, they attempt to represent each variable according to the latest researches.

Hejazi \& Hosseini Moghaddam (1392) have studied "the effect of entrepreneurship tendency on the performance of banks with the emphasis on the mediating role of market orientation (case study: public and private banks of Gilan province)". Results of the research hypotheses, along with proving the effect of market orientation on performance, show that generally there is direct and indirect relationship between entrepreneurship and function and marketing variable has a significant effect on this relationship.

Arabi et al., (1392) have conducted a study entitled "study of gaining competitive advantage and improving organizational performance through customer-orientation, distinction of innovation and market". Results show that customer-orientation has a positive and significant effect on innovation and marketing. Moreover, innovation and marketing have a positive and significant effect on organizational function.

Madhoushi et al., (1391) have studied "the effect of market orientation and entrepreneurial tendency on innovation in small and medium businesses in the current changing and unstable conditions". According to the results, the promotion of market orientation enhances innovation directly and indirectly by means of entrepreneurial tendency. 


\section{Foreign Studies}

Sandeep et al., (2013) have conducted a study entitled "competition through service innovation: the role of resource combination and entrepreneurship in project-oriented companies in Australia and America. In this research, multi-stages research program was used to demonstrate the way the strategic resources of innovative and entrepreneur service companies combine and proceed their competitors. This research acts as an encouragement to go through this subject deeply.

Lee Jia-Sheng \& Hsieh Chia-jung did a study entitled "investigating the relationship among entrepreneurship, marketing capacity, innovation capacity and sustainable competitive advantage". The dependent variables in this study are the sustainable competitive advantage and the effective variables namely, innovation capacity and entrepreneurship. In this research, more than 1000 Taiwanese manufacturers, who have studied in the commonwealth magazine in Taiwan in 2009, are investigated.

Vikash Naidoo in his study entitled "the survival of the company forms a crisis: the effect of market orientation, marketing innovation and business strategy" conclude that small and medium Chinese manufacturing companies which promote and retain competitive advantage, have a bigger chance of survival and marketing innovation helps developing the competitive advantage through cost and differentiation leadership strategy.

Prajogo, D.I., McDermott et al., in their research, "impact of value chain activities on quality and innovation" conclude that research management and development has a positive effect on the product innovation. Their research also displays that factors such as focus on customer, management of process and distribution channel influence the quality of products.

Moreover, management of distribution channel has a positive effect on product innovation.

\section{Research Methodology}

This research in terms of purpose is practical based on descriptive- survey and causal-based approach. Subject area of the research is the study of the relationship between service entrepreneurship and interactive innovation with a sustainable competitive advantage. The sphere of the study is Ahwaz University of Medical Sciences. The data are analyzed by SPSS software in three stages namely, 1. Understanding the data and preparing them for analysis 2.

Performing the validity and reliability tests of the criteria 3. And the analysis of the proposed conceptual model. The conceptual model analyzes the hypotheses based on Sandeep model (2013).

Data Analysis.

This part is committed to data analysis and the results. Research variables in table (1) are as follows:

Correlation Test.

\section{Analysis of the first hypothesis}

Table 1. Correlation coefficient of service entrepreneurship and interactive innovation

\begin{tabular}{|l|l|l|l|l|l|}
\hline $\begin{array}{l}\text { Independent } \\
\text { variable }\end{array}$ & $\begin{array}{l}\text { Statistical } \\
\text { index } \\
\text { Dependent } \\
\text { variable }\end{array}$ & $\begin{array}{l}\text { Correlation } \\
\text { coefficient } \\
\left(\mathrm{R}^{2}\right)\end{array}$ & $\begin{array}{l}\text { Significance } \\
\text { level } \\
(\mathrm{p})\end{array}$ & $\begin{array}{l}\text { Number } \\
\text { of } \\
\text { samples } \\
(\mathrm{n})\end{array}$ & Test result \\
\hline $\begin{array}{l}\text { Service } \\
\text { entrepreneurship }\end{array}$ & $\begin{array}{l}\text { Interactive } \\
\text { innovation }\end{array}$ & $78 \%$ & $0 / 00$ & 150 & $\begin{array}{l}\text { Test } \\
\text { significance }\end{array}$ \\
\hline
\end{tabular}

Source: researcher's calculations 
According to the above table, the significance level is calculated as 0.00 which is less than the standard 0.05 . Therefore, the relationship between the two variables is approved. The coefficient of determination is measured as $78 \%$, representing that the independent variable of this research justifies $78 \%$ of the dependent variable changes. Moreover, the correlation coefficient is positive which portrays the direct relationship between the two variables. Thus, it can be claimed that the examined independent variable has a significant relationship with the dependent variable.

\section{Analysis of the second hypothesis}

To examine the relationship between two variables of service entrepreneurship and supportive innovation, Pearson correlation coefficient has been used and zero assumption is chosen as follows. By conducting the test at the level of $95 \%$, the following results were given:

Table 2. correlation coefficient of service entrepreneurship and supportive innovation

\begin{tabular}{|l|l|l|l|l|l|}
\hline $\begin{array}{l}\text { Independent } \\
\text { variable }\end{array}$ & $\begin{array}{l}\text { Statistical } \\
\text { index } \\
\text { Dependent } \\
\text { variable }\end{array}$ & $\begin{array}{l}\text { Correlation } \\
\text { coefficient } \\
\left(\mathrm{R}^{2}\right)\end{array}$ & $\begin{array}{l}\text { Significance } \\
\text { level } \\
(\mathrm{p})\end{array}$ & $\begin{array}{l}\text { Number } \\
\text { of } \\
\text { samples } \\
(\mathrm{n})\end{array}$ & Test result \\
\hline $\begin{array}{l}\text { Service } \\
\text { entrepreneurship }\end{array}$ & $\begin{array}{l}\text { Supportive } \\
\text { innovation }\end{array}$ & $96 \%$ & $0 / 00$ & 150 & $\begin{array}{l}\text { Test } \\
\text { significance }\end{array}$ \\
\hline
\end{tabular}

Source: researcher's calculations

Based on the above table, the significance level is calculated as 0.00 which is lower than the standard 0.05 . Therefore, the relationship between the two variables is approved. The coefficient of determination is measured as $96 \%$, which displays that the independent variable of this research justifies $96 \%$ of the dependent variable changes. Moreover, the correlation coefficient is positive which portrays the direct relationship between the two variables. Thus, it can be claimed that the examined independent variable has a significant relationship with the dependent variable. That is, there is a direct relationship between service entrepreneurship and supportive innovation.

\section{Analysis of the third hypothesis}

Here, to investigate the relationship between the two variables of mutual relationships and brand special value, Pearson correlation coefficient is employed and zero assumption is chosen. By conducting the test at the level of $95 \%$, the following results were given:

Table 3. correlation coefficient of interactive innovation with sustainable competitive advantage

\begin{tabular}{|l|l|l|l|l|l|}
\hline $\begin{array}{l}\text { Independent } \\
\text { variable }\end{array}$ & $\begin{array}{l}\text { Statistical } \\
\text { index } \\
\text { Dependent } \\
\text { variable }\end{array}$ & $\begin{array}{l}\text { Correlation } \\
\text { coefficient } \\
\left(\mathrm{R}^{2}\right)\end{array}$ & $\begin{array}{l}\text { Significance } \\
\text { level } \\
(\mathrm{p})\end{array}$ & $\begin{array}{l}\text { Number } \\
\text { of } \\
\text { samples } \\
(\mathrm{n})\end{array}$ & Test result \\
\hline $\begin{array}{l}\text { Interactive } \\
\text { innovation }\end{array}$ & $\begin{array}{l}\text { Sustainable } \\
\text { competitive } \\
\text { advantage }\end{array}$ & $99 \%$ & $0 / 00$ & 150 & $\begin{array}{l}\text { Test } \\
\text { significance }\end{array}$ \\
\hline
\end{tabular}

Source: researcher's calculations

Based on the above table, the significance level is calculated as 0.00 which is lower than the standard 0.05 . Therefore, the relationship between the two variables is approved. The coefficient of determination is measured as $99 \%$, which displays that the independent variable of this research justifies $99 \%$ of the dependent variable changes. Moreover, the correlation 
coefficient is positive which portrays the direct relationship between the two variables. Thus, it can be claimed that the examined independent variable has a significant relationship with the dependent variable. That is, there is a direct relationship between interactive innovation and sustainable competitive advantage.

\section{Analysis of the fourth hypothesis}

Here, to investigate the relationship between the two variables of supportive innovation and sustainable competitive advantage, Pearson correlation coefficient is employed and zero assumption is chosen. By conducting the test at the level of $95 \%$, the following results were given:

Table 4. correlation coefficient of supportive innovation with sustainable competitive advantage

\begin{tabular}{|l|l|l|l|l|l|}
\hline $\begin{array}{l}\text { Independent } \\
\text { variable }\end{array}$ & $\begin{array}{l}\text { Statistical } \\
\text { index } \\
\text { Dependent } \\
\text { variable }\end{array}$ & $\begin{array}{l}\text { Correlation } \\
\text { coefficient } \\
\left(\mathrm{R}^{2}\right)\end{array}$ & $\begin{array}{l}\text { Significance } \\
\text { level } \\
(\mathrm{p})\end{array}$ & $\begin{array}{l}\text { Number } \\
\text { of } \\
\text { samples } \\
(\mathrm{n})\end{array}$ & Test result \\
\hline $\begin{array}{l}\text { Interactive } \\
\text { innovation }\end{array}$ & $\begin{array}{l}\text { Sustainable } \\
\text { competitive } \\
\text { advantage }\end{array}$ & $89 \%$ & $0 / 00$ & 150 & $\begin{array}{l}\text { Test } \\
\text { significance }\end{array}$ \\
\hline
\end{tabular}

Source: researcher's calculations

Based on the above table, the significance level is calculated as 0.00 which is lower than the standard 0.05 . Therefore, the relationship between the two variables is approved. The coefficient of determination is measured as $89 \%$, which displays that the independent variable of this research justifies $89 \%$ of the dependent variable changes. Moreover, the correlation coefficient is positive which portrays the direct relationship between the two variables. Thus, it can be claimed that the examined independent variable has a significant relationship with the dependent variable. That is, there is a direct relationship between interactive innovation and sustainable competitive advantage.

A general research model in the form of structural equations.

After confirming each of measurement patterns, to test the hypotheses, a general research model is represented in the form of structural equations in figure (1) and (2). Model's general indices of fitness assessment, are demonstrated in table number (5), which represent that the modulated model is appropriate in terms of the three indices of absolute fit, comparative and economical.

Table 5. Fit indices of the overall research model

\begin{tabular}{|l|l|l|}
\hline $\begin{array}{l}\text { Indicator and standard of } \\
\text { acceptance }\end{array}$ & $\begin{array}{l}\text { Indicator value in the } \\
\text { desired pattern }\end{array}$ & result \\
\hline $1 \chi^{2} / \mathrm{df} \leq 5$ & 2 & Pattern fit is appropriate. \\
\hline $\mathrm{GFI} \geq 0 / 90$ & $0 / 903$ & Pattern fit is appropriate. \\
\hline $\mathrm{AGFI} \geq 0 / 8$ & $0 / 845$ & Pattern fit is appropriate. \\
\hline $\mathrm{RMR} \leq 0 / 05$ & $0 / 029$ & Pattern fit is appropriate. \\
\hline $\mathrm{NFI} \geq 0 / 90$ & $0 / 935$ & Pattern fit is appropriate. \\
\hline $\mathrm{CFI} \geq 0 / 90$ & $0 / 951$ & Pattern fit is appropriate. \\
\hline $\mathrm{RMSEA} \leq 0 / 05$ & $0 / 004$ & $\begin{array}{l}\text { Pattern fit is mostly } \\
\text { appropriate. }\end{array}$ \\
\hline $\mathrm{TLI} \geq 0 / 90$ & $0 / 933$ & Pattern fit is appropriate. \\
\hline
\end{tabular}




\section{Hypotheses Test}

After the investigation and confirmation of the measured pattern in the first step, and the confirmation of the general model in the second step, structural equations are used for hypothesis test and subsequently, the subsidiary hypotheses have been discussed.

Root mean square error approximation equals 0/004 in the selected model which demonstrates the adequacy of fit model and its strong significant relationship.

Path analysis of subsidiary variables will be discussed.

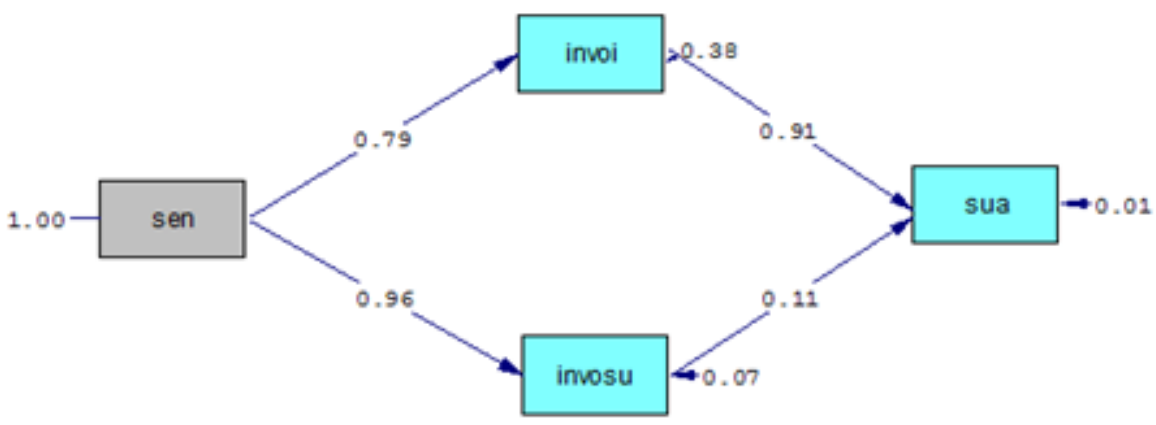

Chi-Square $=12.90, \mathrm{df}=2, \mathrm{p}-\mathrm{value}=0.00158, \mathrm{RMSEA}=0.0041$

Fig. 1. path analysis and path coefficients of the model resulted from LISERL software based on subsidiary variables

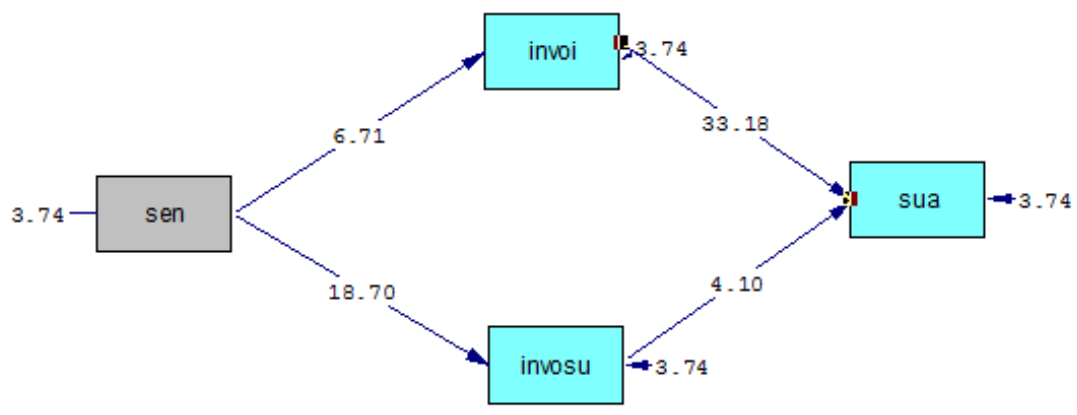

Chi-Square=12.90, df=2, $\mathrm{P}$-value $=0.00158, \mathrm{RMSEA}=0.0041$

Fig. 2. path analysis and path coefficients of the model resulted from t-test LISERL software

Table 6. fir indices according to the main components

\begin{tabular}{|l|l|l|l|}
\hline Overall fit indices & Coefficient & t-value & Coefficients \\
\hline $\begin{array}{l}\mathrm{X}^{2}=12 / 90 \\
\mathrm{Df}=2 \\
\mathrm{p}-\mathrm{valuel}<.005\end{array}$ & $\begin{array}{l}\text { Service } \\
\text { entrepreneurship and } \\
\text { interactive innovation }\end{array}$ & $6 / 71$ & $79 \%$ \\
\hline & $\begin{array}{l}\text { Service } \\
\text { entrepreneurship and } \\
\text { interactive innovation }\end{array}$ & $18 / 70$ & $96 \%$ \\
\hline
\end{tabular}




\begin{tabular}{|l|l|l|l|}
\hline & $\begin{array}{l}\text { Interactive innovation } \\
\text { and sustainable } \\
\text { competitive advantage }\end{array}$ & $33 / 18$ & $91 \%$ \\
\hline & $\begin{array}{l}\text { Supportive innovation } \\
\text { and sustainable } \\
\text { competitive advantage }\end{array}$ & $40 / 10$ & $11 \%$ \\
\hline
\end{tabular}

Source: researcher's calculations

\section{Conclusion and Suggestions}

Today, entrepreneurship is one of tools of development because the existence of entrepreneurs provides an opportunity for success and development. Also, due to the everincreasing number of new competitors and the distrust in traditional management practices in companies, the necessity of entrepreneurship is felt. In this regard, the dynamic organizations are responsible to discover and retain innovator entrepreneurs. To retain autonomous and innovative people, an organization requires an appropriate structure and innovative managers.

The organization which is unable to fulfill its potentialities, will soon be defeated by other organizations which have the capability in employing talents and offering new products at the lowest cost and they are also run by competent with high point of view.

Tools are needed to achieve entrepreneurship. One of the tools is an organizational structure consistent with entrepreneurship concepts which is less regarded.

In today's evolving world, regarding the environmental unreliability, constant changes and various challenges, one of the effective methods for companies' survival and their adaption to the rapid evolutions is the tendency to entrepreneurship and becoming innovative organizations. Many organizations have noticed the importance of entrepreneurship and service entrepreneurship. In fact, a change in the strategy is a response to a need resulted from the vast evolutions and threats. Thus, the society and the organization can make progress if they use the opportunities properly. In institutions such as service companies and banks which have a mutual and multiple relationships with customers, market orientation can be helpful way for performance improvement. Through a direct response to customers' requirements, market orientation may lead to innovation in the product and process which is a crucial dimension in entrepreneurial orientation.

\section{According to the results, the suggestions are as follows}

Regarding the results which represent that market learning ability in parallel with sustainable competitive advantage. Therefore, there are more researches needed to study the effect of innovation on sustainable competitive advantage in companies. Moreover, given that various factors influence the sustainable competitive advantage, it is suggested that the future researches investigate the predictor factors of sustainable competitive advantage. For instance, since the organizational resources which provide the activities are limited, it is suggested that further studies investigate the relationship between the company sources, sustainable competitive advantage and development of learning abilities provided by the company.

Separate researches on compound model in other industries of the country, especially service industries namely, tourism, insurance, hospitals are suggested.

It is suggested that in the future studies, predictor dimensions and factors which assure the organization's progress in short term of profitability and long term of survival and finally promote the sustainable competitive advantage regarding cultural conditions and dominant rules, will be examined. 


\section{REFERENCES}

1. Ardakani, S, et al., (1388). "Entrepreneurial creativity and behavior", the second national conference of creativity, Tehran.

2. Baker, T. \& Nelson, R. E. (2005). Creating something from nothing: Resource construction through entrepreneurial bricolage. Administrative Science Quarterly, 50(3), 329-366 Bitner, M. J., \& Brown, S. W. (2008). The service imperative. Bus Hor, 51(1), pp. 39-46.

3. Baker, T. (2007). Resources in play: Bricolage in the Toy Store (y). journal of business venturing, 22, pp. 694-711. doi: 10.1016/j.jbusvent.2006.10.008.

4. Casciaro, T. \& Piskorski, M. J. (2005). Power imbalance, mutual dependence, and constraint absorption: A closer look at resource dependence theory. Administrative Science Quarterly, 50(2), pp. 167-199.

5. Chegeni, H. (1388). "Entrepreneurship and the effect of information technology on it". Amirkabir magazine of entrepreneurs, 55, pp. 11-13.

6. Hejazi, S; Hosseini Moghadam, S. (1393). "the impact of entrepreneurial orientation on the performance of banks through market mediation", entrepreneurship development, pp. 221-229.

7. Hipp, C. \& Grupp, H. (2005). Innovation in the service sector: the demand for servicespecific innovation measurement concepts and typologies. Research Policy, 34(4), pp. 517-535.

8. J Kigan et al., (1394). "Global Marketing Management". Translator: Abdolhamid Ebrahimi, publication office of cultural studies.

9. Lee J. S. \& Hsieh C. J. (2010). A Research in Relating Entrepreneurship, Marketing Capability, Innovative Capability and Sustained Competitive Advantage. EABR \& ETLC Conference Proceedings.

10. Madhoushi, Mehrdad; Tayebi, Mohammad reza. (1391). "the effect of market orientation and entrepreneurial tendency on innovation in small and medium businesses". Journal of commerce research. Number 65. Winter 1391, pp. 115-136.

11. Movaghar, M; Mousavi Diva, M. (1393). "Investigating the role of service entrepreneurship and bricolage in sustainable competitive advantage: specification of the role of interactive and supportive innovation". The second national conference of entrepreneurship and competitiveness.

12. Naido, V. (2010). Firms survival through a crisis: the influence of market orientation, marketing innovation and business strategy. industrial marketing management, 39, pp. 1311-1320.

13. Naiyeri, A; Dashti pour, M; Moradi, F. (1394). "Determining the role of market orientation role in promoting the level of organizational innovation in banking system (case study: Bank of Hekmat Iranian". The first conference of management and entrepreneurship in conditions of resistance economics, pp. 46-52.

14. O'Cass, A. \& Ngo, L. V. (2010). Examining the firm's value creation process: A managerial perspective of the firm's value offering strategy and performance. British Journal of Management no- 0 .

15. Porter, M. E. (1985). Competitive advantage: Creating and sustaining superior performance. New York, NY: Free Press.

16. Rahimian, $\mathrm{M}$ et al., (1388). "IT, a base for entrepreneurship" Magazine of work and society, 112, pp. 63-70.

17. Rahman Seresht, H, Hashemi, K. (1378). "The process and strategy of innovation in Iranian construction companies". Management perspective. 
18. Sandeep Salunke. (2013). Competing through service innovation: The role of bricolage and entrepreneurship inproject-oriented firms, Journal of Business Research 66, pp. 1085-1097. Weerawardena, J., \& O'Cass, A. (2004). Exploring the characteristics of themarket-driven firms and antecedents to sustained competitive advantage. Industrial marketing management, 33, pp.419-428.

\section{Article history: \\ Received 19 March 2018 \\ Accepted 10 May 2018}

